\section{Dr. E. J. Allen, C.B.E., F.R.S.}

THE Rev. Richard Allen of Lancashire, and his wife Emma Johnson, of Bideford in Devon, had good reason to be proud of their family of eight, which consisted of five sons and three daughters, four of whom survive. The sons were the late Dr. H. N. Allen, professor of electrical engineering and afterwards principal of the College of Science at Poona; the late Mr. C. B. Allen, assistant general manager of the Midland Bank; the late Dr. E. J. Allen, F.R.S., until 1936 director of the Marine Biological Laboratory at Plymouth; Mr. E. L. Allen, of the School of Art, Redditch ; and Dr. H. S. Allen, F.R.S., professor of natural philosophy at St. Andrews.

Edgar Johnson Allen, the second son, was born at Preston in 1866, educated at Kingswood School, Bath, and at the Yorkshire College, Leeds. He graduated as an external student of the University of London with honours in chemistry in the Intermediate B.Sc. (1884) and physics in the Final B.Sc. examination (1885). For financial reasons some years were spent in teaching posts, including the headmastership of a school in the West Indies. After his return to Europe, he was engaged in post-graduate study in zoology in the University of Berlin and also at University College, London. In 1900 he graduated as D.Sc. in the University of London and won the Sherbrooke Scholarship. He had already received a research grant from the Royal Society (1893) which enabled him to work at Plymouth.

In 1895 he became director of the Marine Biological Association's Plymouth Laboratory and secretary to the Council, posts which he held for forty-two years, until his retirement in 1936 . Under his guidance the Laboratory prospered and became a centre of marine research. It became a centre of physiological research also, for Allen realized the importance of marine animals and plants as subjects for the study of general problems of biology and medicine. Accordingly, it came about that the last scientific paper read by one of his old staff on his way to take up duty as a naval officer was before the Royal Society of Medicine upon the semi-circular canals of the ear, studied through the response of single nerve fibres.

During the earlier years much of the research and the observational work at sea were carried out by Allen himself. But as years went on his duties as director became more arduous and his time was occupied with routine, with advising younger men and attending to the wants of the numerous research workers who came to the Laboratory from distant lands. The impact of the visitors upon the regular staff was, in his view, specially good for the latter, and tended to prevent the departmental miasma of an official laboratory from enveloping them. It was, therefore, a pleasure to him when his attention was directed to Sir Lawrence Bragg's presidential address to the Institute of Physics last July and it was suggested that his moulding of a research institution was upon the lines considered by Bragg to be most desirable.

But though his unremitting and unselfish care for his laboratory left him little time, Allen contrived also to be a good Plymothian and served upon a number of committees. He gave much thought also to the Tees and Mersey Survey Committees of the Department of Scientific and Industrial Research and to the work of the Water Pollution Research Board.

Allen's work brought him general recognition in the learned world. In 1914 he was elected a fellow of the Royal Society. In 1922, at Hull, he wais president of the Zoological Section of the British Association. In 1923 the Hansen Memorial Medal and Prize came to him from Denmark. In 1926 he received the Gold Medal of the Linnean Society, followed by the Darwin Medal of the Royal Society in 1936 and the Agassiz Medal for Oceanography of the National Academy of Sciences, Washington. In the previous year he had been made C.B.E. He was also a foreign member of the Royal Academy, Denmark, and an hon. LL.D. of the University of Edinburgh.

Of Allen's forty-three published papers and addresses, twenty-five appeared in the Journal of the Marine Biological Association, which he edited for so long. Some of his best early work on the nervous system of the Crustacea appeared in the Quarterly Journal of Microscopical Science, and other work on crustacean embryology and histology appeared in the Proceedings of the Royal Society; while his work on regeneration and reproduction of the Syllid Procerastea was published in the Philosophical Transactions. His work on the culture of planktonic diatoms opened up a trail which has since been actively followed. Of his papers two, on estuarine fauna, were with R. A. Todd. The first diatom paper was with the late E. W. Nelson and in two, dealing with the genetics of Gammarus, he collaborated with Mrs. E. W. Sexton.

E. J. Allen's end came peacefully on December 7 after one day of indisposition, while still full of interests and enjoying a retirement with leisure he had previously lacked.

W. R. G. Atkins.

\section{Lieut. W. Neil Paton, D.S.C., R.N.V.R.}

AFter many valiant aerial combats, which won him the Distinguished Service Cross and a mention in dispatches, William Neil Paton was reported missing off Malta in June last and has now been officially presumed killed. Marine biology has lost a recruit of great promise. Born in September 1914, the second son of Dr. and Mrs. J. Hunter P. Paton of St. Andrews, he was educated at Oundle and Magdalen College, Oxford. After graduating in 1937 he joined the Oxford University Expedition to Grand Cayman and returned in the following summer with a rich zoological collection. He then joined me in experimental work on the vertical migration of the marine plankton being carried out at the Millport Marine Station and was later appointed to the research staff of the Station.

Soon after the outbreak of war, Paton volunteered for service with the R.N.V.R., and received his commission in the spring of 1940. Later he transferred to the Fleet Air Arm and was stationed at Malta. The Admiralty reported the award of the D.S.C. in the following terms: "for outstanding courage and determination in the face of the enemy. This officer carried out sixteen air operations from Malta in all of which he made contact with the enemy and in seven of which enemy shipping was destroyed or damaged. On eight of the operations he was leading the force and was largely responsible for its success". He was mentioned in dispatches for his last action: "the enemy ships, escorted by a strong force of shorebased fighters, were attacking an allied convoy bound for Malta when our aircraft engaged them and pressed home a determined attack in the face of bitter resistance". 